\title{
Harry potter and the prisoner of azkaban: The signs analysis of its cover
}

\author{
Debiga Fikky Abdullah $^{1}$, Lusia Kristiasih Dwi Purnomosasi ${ }^{1}$ \\ 1, Department of English Teaching, Universitas PGRI Madiun, Indonesia
}

\begin{tabular}{l}
\hline Article Info \\
\hline Article history: \\
Received January 4, 2018 \\
Revised March 25, 2018 \\
Accepted Mei 30, 2018 \\
\hline
\end{tabular}

\section{Keywords:}

Harry Potter and The Prisoner of Azkaban

Popular Culture

Popular Literature

Semiotic

Ideology

\begin{abstract}
This research is conducted to explain the implementation, the problems, and the solutions of problems in the Implementation of Sandwich Graphic Organizer in Teaching Writing to the Tenth Grade Students of SMAN 1 Jiwan in the schooling year of 2016/2017. This research uses descriptive qualitative research. The participants of the research are the English teacher and students of X-A class of SMAN 1 Jiwan. The research uses purposive sampling technique. The techniques which are used to collect the data are observation, interview, and documentation. While, the techniques of the data analysis are: data condensation, data display, and conclusion and verification. The results of this research are the teacher prepares syllabus, $R P P$, and the papers of picture Sandwich Graphic Organizer. The steps are pre-activities, whilst-activities, and post-activities. Otherwise, some students get difficulties in managing their time, some students make mistakes in using V2 that is used in writing recount text, some students get difficulties in expressing their ideas from Indonesian to the English language because of minimum of vocabulary, and some students forget to write a capital letter in the beginning of the sentence and full stop in the ending of the sentence. Then, the solutions of problems in the implementation Sandwich Graphic Organizer are: the teacher explains again about the steps of using technique Sandwich Graphic Organizer, the teacher divides the time of the students when the students should write the outline and when the students should develop their outline, the teacher gives the command for the students to open their dictionary to check the list of verb 2, the teacher asks the students to open their dictionaries when they are difficult in translating their ideas, and the teacher asks the students to pay attention to the punctuation when writing.
\end{abstract}

Copyright (C) 2018 Department of English Teaching. All rights reserved.

\section{Corresponding Author:}

Debiga Fikky Abdullah,

Department of English Teaching,

Universitas PGRI Madiun,

Jalan Setiabudi No.85 Madiun, Eas Java, Indonesia.

Email: debigafikky@gmail.com

\section{INTRODUCTION}

It is not difficult to depict the salient realm which is sought by the popular literature; capital (Adi, 2010: 21). This prevailing concept thus legitimates that popular literature is the inexorable accoutrements of production, distribution, and consumption (Briggs, 2007: 115; Adi, 2010: 40) which would not require people to think (Briggs, 2007: 117). To have this the author have to attribute the array of many things. The understanding of people's culture is the social circumstance and the kind of classes in the society ultimately deem as the important formula. This is something that has successfully done with Harry Potter. People love the way J. K. Rowling, the author, persuades the readers by creating the story about supernatural or the chimera which contains the nature and manifestations of evil. She also said that as long as human race subsist, the most common theme in children's literature is magic (Nye, 2001: 137). 
As the product of popular literature which has been the worldwide fiction phenomenon, Harry Potter brings the readers around the world into the new fantasy of wizard. During its successful Harry Potter uses book cover in each series attaching the attracting items. Those that will be discussed, considered as the interpretation of the author's notion in making the covers. Those items supersede the modernity which is value that popular literature suppose to deliver in gaining the reader's curiosity, with the antediluvian properties.

Such prominent items catch the researcher's interest to explore how they are revealed and uncover how those items convey their meaning then affect the readers. The research in the current study, likewise, focuses on the details of not only the meaning of the items but also the underlying value of accumulated ones which imply the ideology by incorporating and from the viewpoints of the items under study. Analyses are centered on items attached.

Among Harry Potter series, Harry Potter and The Prisoner of Azkaban is the series which contains the key story which has been the stepping stone to develop the next series. Its cover is already attached by some pictures which correlate with the value that designate the characteristic of popular literature. It is interesting, accordingly, to reveal the meaning, which is grounded in the conjunction of sound -image, object and concept (Denzin, 1987: 3), of the items that have been attached in the book cover of Harry Potter and The Prisoner of Azkaban. Among approaches which enable the researcher to arrive at the planned objectives, the semiotic approach (Adi, 2010: 225) is embraced. Semiotic approach is chosen because of its characteristic which using special concept in gaining the meaning of the sign and its effort to reveal how sign is created. These are considered as the differentiation of semiotic with another sciences (Saussure, 1966: 20 in Hussein and Abushihab, 2014: 58). The using of semiotic also gives the easier way to understand the construction of sign within the society (Thibault, 1997 in Hussein and Abushihab, 2014: 58), and structures our interpretations of the symbolic and economic realities of everyday life (Denzin, 1987: 2). Thus, the researcher will use Umberto Eco's semiotics since it is considered as the most suitable theory within this research. The Umberto Eco's theory gives the deep understanding on how the meanings from the signs attached in Harry Potter and The Prisoner of Azkaban's book cover. In the end of the effort, ideology of the Harry Potter and The Prisoner of Azkaban will be revealed.

Ideology is the association of thinking which applied in the society. It is brought by the combination of symbols which appear mostly set for the other object (Cohen, 1985: 72). Those objects then give people the way how they interpret its meaning. They have an authority such doing so is because the symbols do not provide them with the ones which ready to be taken. It is such vocabularies which gives freedom for the people to interpret the meaning, but do not serve with the already one. To reveal the ideology that has already existed in the society, Julia Kristeva's work is used.

In her form, ideologeme, the meaning of something is the result between two elements; a given textual arrangement and sequences. She explains that a given textual arrangement is the semiotic practice. It means that the element of the arrangement will need more interpretations. This process considered as the difficult one knowing that it is not depend on one structures but some. The process of interpretation of course direct the thinker or the reader to use not only their knowledge that they already have, but also the ability to imagine what kind of thing which appropriate to be gathered with the notion. Knowledge is the background in the reader's mind that equipped them with choices, while the notion is also the subject they have to 
choose. The combination between the knowledge and the ability to interpret will result the right meaning, after it correlates with the sequences. Sequence is the order in which things happen or should happen. The majority of meaning building is the consequences within the sequence. It strings the reality which occurs in the society into parts. These parts direct into the understanding of whole signs embedded with the meaning. Thus, using this analogy the ideologies are revealed.

\section{METHOD}

The research about Harry Potter and The Prisoner of Azkaban: The Analysis of Its Cover is conducted by using qualitative research method. The qualitative research is used because of its characteristic which appropriate with this research. Based on its nature, qualitative research provides the researcher with the nominal rather than numerical sorts of data (Berg, 2001: 6). The qualitative research method provides the reader description-narration analysis which make the understanding of the reseach and the application to the other cases easier (Sutopo, 2006: 1 in Nurhikmawati, 2013: 38). The comprehensive explanation of the description-narration covers the verbal and visual elements, the meaning of the verbal and visual elements which formed as signs, also the ideology which revealed by the semiotics study of Harry Potter and The Prisoner of Azkaban's book cover.

It, however, asks not how people feel but how things work. In explaining the analysis which combines the primary and the secondary data, qualitative research method facilitates the way researcher should elaborate those data. Stake also states that although qualitative research offers such as interpretive, experience based, situational, and personalistic, he believes that interpretation is the hardest one. Considering that there is a phenomenon in this research is revealed by comprehensive treatment. $\backslash$

The phenomenon which has been observed in this research is about the nature of the popular literature that should gives the readers or amuse them with the modernity value. Popular literature especially uses brand new thing in order to gain as much as profit. Then people in the society are attracted to buy the formidable work. The contrary has been shown by the cover of the Harry Potter. How the ancient things in the Harry Potter and The Prisoner of Azkaban catch the reader's attention, still it also gains the big attention of the readers in the society.

\section{RESULT AND DISCUSSION}

The criptic and mysterious nuance are built within the cover. Those things are revealed using the theory of sign from Eco, which focus on the communicative signs. Such nuance is the combination of the colours. This understanding is gained during the investigation of the book cover. The second one is the act of rebellion. The fonts which is used in the cover clearly shows where the story will be brought by the author. Contextual framework is also drawn by such images. The combination between the first and second findings denotes its part. This role is given to the book cover since its function is conveying the message within the story in order to gain as much as profit (Gallagher, 2015: 7).

A profit is mentioned as the main purpose of a product of popular literature (Adi, 2010: 21). In his thesis, Gallagher mentioned the fact from the study which has been conducted by Kamphuis. The fact shows what affects the readers in buying a book, those are: (a) the author, (b) the publisher, and (c) the cover (Gallagher, 2015: 7). The readers want to know who has written the book. From here the quality of a book is 
known based on the quality of the writer itself. Then, people will check the author. They really concern on what media the book is printed. Both the quality of the paper and the binding could affect the reader's decision. However, the two previous elements that have been mentioned are printed on the cover. So, the visual image as the representation should be the first (Gallagher, 2015: 6).

Although, there is an essential role which is done by a book cover, but there is a different between the contemporer cover and the previous one. The latter includes Harry Potter and The Prisoner of Azkaban's book cover which directs into two main findings from its signs interpretation. Gallagher found that recently published books are not designed as a narrative representation of a story within the book like the previous did. Instead, the modern book cover emphasizes the experience of reading the book (Gallagher, 2015: 10).

The findings that have been found in Harry Potter and The Prisoner of Azkaban's book cover analysis are supported with the study which has been conducted by Gallagher. He states that the images have two primary functions, those are: to convince the reader to buy the book and to recreate the experience of reading the book. Further, his study finds that those goals are accomplished through a combination of the symbolic attributive and symbolic suggestive processes (Gallagher, 2015: 11). Correlates with the findings of this study, the cryptic nuance and the act of rebellion are the representation of the symbolic attributive of Gallagher's. The continuation of both findings results the symbolic suggestive processes which accomplish through the reader's interpretation. Such interpretation could be changed by modifying the elements as the primary ingredients. The big question is, who can change such requisite element, and how? The answer is the publisher and designer (Salmani and Eghtesadi, 2015: 1185). Holding the right whether performing the work of an author to the reader or not, publisher get the power in deciding the releasing process of a book. The publisher could easily contact the designer of the cover to create the design cover exactly as they want. Such effort is pertinent if the publication can affect the life of the publishing company.

\section{CONCLUSION}

Since a long time ago, culture has been developing during the dynamic change in human's life. As the representation of a major measurement within the society, culture is a standart on the civilization (Koentjaraningrat, 2009: 144). Culture covers the way of thinking of the people. It directs people to demand the progressive change which is popular culture. The latter is considered as the culture which accomodates the development on how people have to be more conscious. This sensible society then hold the decision whether they will accept something that is served to them or not. It also touch the way they handle the literature. Featuring the popular culture, the recent literature has transformed into popular literature which has a main purpose as a means to gain as much as profit (Adi, 2010: 21). Harry Potter and The Prisoner of Azkaban novel is also the same. It contains the story which is match with the demand of people; amusement. Thus, this book has a cover which tell the reader its meaning and ideology by its signs. This study results the findings from the problems:

1. The cover of Harry Potter and The Prisoner of Azkaban brings the mysterious nuance. Such nuance is built by the combination of the secondary colour blends with darkness of the story, bring the reader in order to play with the fantasy. It is fantasy that derives from a sophisticated experience combined with a sophisticated knowledge. 
2. Then, it results the understanding about the essential purpose of an old value. The value which legitimates the need of being natural and back to the nature. The old value and its legitimation are considered as a form of romanticism which is captured as the ideology.

This research uses Harry Potter and The Prisoner of Azkaban's book cover as its main object. Theories of sign, culture, pop-culture, and pop-literature have been used as the means to analyze it. The readers are suggested to gain more data and information using such theory with different methods. They can bring a lot of data by interviewing the target reader of Harry Potter series. Then, they do a survey on what items that mostly catch their attention. That is the way in order to get a comprehensive and more detailed data. The data will fulfill the need in understanding signs which are used on the book cover. The understanding then makes the readers respect more values from within. Besides, the thing in the story such as a wand, can be compared with the believe in Javanese society about keris. It is interesting, to know the result by using comparison study.

\section{REFERENCES}

Adi, I.R. (2010). Fiksi Populer Teori dan Metode Kajian. Yogyakarta; Pustaka Pelajar.

Ary, D., Jacobs, L.C., Sorensen, C.K., Razavieh, A. (2010). Introduction to Research in Education (8th ed). California; Wadsworth Cencage Learning.

Berg, B.L. (2001). Qualitative Research Methods for The Social Sciences (4th ed). Massachusetts; Allyn and Bacon.

Chandler, D. (2002). Semiotics: The Basics (2nd ed). New York; Routledge.

Cohen, A.P. (1985). The Symbolic Construction of Community. New York; Tavistock Publications Limited.

Denzin, N.K. (1987). On Semiotics and Symbolic Interactionism. Wiley Society for The Study of Symbolic Interaction, 10(1), 1-19.

Forest, M. (2007). Peirce and Semiotic Foundationalism. Indiana University Press, 43(4), 728-744.

Gallagher, D.P. (2015). The Look of Fiction: A Visual Analysis of the Front Covers of The New York Times Fiction Bestsellers. Tesis tidak diterbitkan. Michigan: College of Liberal Arts, Rochester Institute of Technology.

Hussein, B.A., Abushihab, I. (2014). A Critical Review of Ferdinand de Saussure's Linguistic Theory. Canadian Academy of Oriental and Occidental Culture, 8(1), 57-61.

Koerner, E.F.K. (1971). Ferdinand de Saussure. Origin and Development of His Linguistic Theory in Western Studies of Language: A Critical Evaluation of the Evolution of Saussurean Principles and Their Relevance to Contemporary Linguistic Theories. Disertasi tidak diterbitkan. British Columbia: Department of Modern Languages, Simon Fraser University.

Koentjaraningrat. (2009). Pengantar Ilmu Antropologi. Jakarta; Rineka Cipta.

Leeuwen, T.V. (2005). Introducing Social Semiotics. New York; Routledge.

Miles, M.B., Huberman, A.M. (1994). An Expanded Sourcebook: Qualitative Data Analysis. California; Sage Publications, Inc.

Nurhikmawati, A.R., (2013). Analisis Semiotika Sosial Iklan Cetak Parfum dalam Majalah Cosmopolitan. Tesis tidak diterbitkan. Yogyakarta: Fakultas Ilmu Budaya, Universitas Gadjah Mada.

Nye, L. (2001). Harry Potter and The Sorcerer's Stone, Harry Potter and The Chamber of Secrets, Harry Potter and The Prisoner of Azkaban, Harry Potter and The Goblet of Fire: Editor's Review. Harvard Educational Review. 71(1), 136.

Pryor, R.H. (1988). Reading Ideology in Discourse: A history, theory, and case study. Tesis tidak diterbitkan. Illinois: Speech Communication, University of Illinois. 
Salmani, B., Eghtesadi, Zahra. (2015). An Intersemiotic Approach towards Translation of Cover Designs in Retranslated Classic Novels. Academy Publication, 5(6), 1185-1191.

Saussure, F.D. (1959). Course in General Linguistics. New York; Philosophical Library, Inc.

Schneider, C.C. (2009). The Use of Children's Book as a Vehicle for Ideological Transmission. Disertasi tidak diterbitkan. Ohio: Graduate Program in Education: Teaching and Learning, Ohio State University. 